\title{
Deoxyribonucleic Acid Base Compositions of Dermatophytes
}

\author{
By F. D. DAVISON, ${ }^{*}$ D. W. R. MACKENZIE ${ }^{1}$ AND R. J. OWEN ${ }^{2}$ \\ ${ }^{1}$ Mycological Reference Laboratory, London School of Hygiene and Tropical Medicine, \\ London $W C 1 E 7 H T$ \\ ${ }^{2}$ National Collection of Type Cultures, Central Public Health Laboratory, \\ London NW9 5 HT
}

(Received 19 November 1979)

\begin{abstract}
DNA was extracted and purified from 55 dermatophyte isolates representing 34 species of Trichophyton, Microsporum and Epidermophyton. The base compositions of the chromosomal DNA were determined by $\mathrm{CsCl}$ density gradient centrifugation and were found to be in the narrow range of 48.7 to $50.3 \mathrm{~mol} \% \mathrm{G}+\mathrm{C}$. A satellite DNA component assumed to be of mitochondrial origin was present in most strains, with a $\mathrm{G}+\mathrm{C}$ content ranging from 14.7 to $30.8 \mathrm{~mol} \% \mathrm{G}+\mathrm{C}$. Heterogeneity in microscopic and colonial characteristics was not reflected in differences in the mean $\mathrm{G}+\mathrm{C}$ content of the chromosomal DNAs. Strains varied in the $\mathrm{G}+\mathrm{C}$ contents of satellite DNA, but these did not correlate with traditional species concepts.
\end{abstract}

\section{INTRODUCTION}

In distinguishing between species of dermatophytes, the diagnostic laboratory normally relies on morphological characteristics of the cultured micro-organism on agar and on a few simple biochemical tests (Rebell \& Taplin, 1978). However, identification may be difficult as the micro-organisms tend to be variable in their appearance and some undergo the rapid and irreversible degenerative changes associated with pleomorphism. This may occur soon after isolation or on repeated subculturing. The colonies become white and fluffy and, like the microscopic morphology, are devoid of distinguishing features.

The purpose of this study was to determine if differences between species established by traditional criteria were reflected by differences in the molecular composition of their genetic material. It was considered that measurement of the mean DNA base composition of representative dermatophytes might permit more definitive and objective grouping of the species. DNA base compositions are an important and widely used characteristic in microbial classification, and the values are known for several medically important fungal genera, including species of Aspergillus, Candida and Cryptococcus (Normore, 1973). In this study, dermatophyte strains were selected to represent a range of morphological features and geographical origins. Attention was focussed on Trichophyton rubrum and T. mentagrophytes as these two species are commonly encountered in clinical situations and are often difficult to differentiate from one another.

\section{METHODS}

Organisms. The identities and sources of the test isolates are listed in Table 1. They originated from human infections in the United Kingdom, Republic of South Africa, Canada and New Zealand. Other cultures were obtained from the National Collection of Pathogenic Fungi (NCPF), maintained at the Mycological Reference Laboratory (MRL). Two non-dermatophyte species, Scytalidium hyalinum and Hendersonula toruloidea were included as they produce superficial infections clinically similar to those caused by derma- 
tophytes and could be confused with them in specimen material (Gentles \& Evans, 1970; Campbell \& Mulder, 1977).

Growth conditions. The fungi were cultivated on malt agar slants $[4 \%(\mathrm{w} / \mathrm{v})$ malt, $1.5 \%(\mathrm{w} / \mathrm{v})$ agar] containing chloramphenicol $\left(5 \times 10^{-5} \mathrm{~g} \mathrm{l}^{-1}\right)$ to inhibit bacteria and cycloheximide $\left(5 \times 10^{-4} \mathrm{~g} \mathrm{l}^{-1}\right)$ to inhibit non-dermatophytic fungi. The cultures were incubated at $26^{\circ} \mathrm{C}$ for periods that varied from $2 \mathrm{~d}$ to several weeks, depending on the species, until there was sufficient growth to provide a seeding inoculum. This was used to inoculate $250 \mathrm{ml}$ conical flasks containing $100 \mathrm{ml}$ broth medium $[1 \%(\mathrm{w} / \mathrm{v})$ peptone, $4 \%(\mathrm{w} / \mathrm{v})$ glucose, $0 \cdot 1 \%(\mathrm{w} / \mathrm{v})$ Oxoid yeast extract, with chloramphenicol and cycloheximide] which were incubated at $26^{\circ} \mathrm{C}$ on an orbital incubator at $100 \mathrm{rev} \cdot \mathrm{min}^{-1}$ for 4 to $14 \mathrm{~d}$, depending on the strain. The primary cultures were then transferred to 21 baffled conical flasks containing $500 \mathrm{ml}$ broth medium; cycloheximide was excluded at this stage because of its slightly inhibitory effect on dermatophytes. The incubation period depended on the rate of growth. Mycelia, or arthrospores which were sometimes produced in abundance, were harvested by filtration after 5 to $12 \mathrm{~d}$ incubation. The yield ranged from approximately 20 to $50 \mathrm{~g}$ wet wt. Harvested growth was stored in plastic Petri dishes at $-20^{\circ} \mathrm{C}$. Cultures were checked before harvesting to confirm that contaminants were absent and that the colonial and microscopic characters remained compatible with those of the species.

Crude extraction of DNA. About $30 \mathrm{~g}$ of the frozen harvested material was ground to a powder in a prechilled mortar, using liquid nitrogen (Mendonça-Hagler et al., 1974). The triturated material was suspended in $100 \mathrm{ml}$ buffer composed of $0.02 \mathrm{M}$-Tris and $0.01 \mathrm{M}$-EDTA, with the pH adjusted to 7.8 with $1 \mathrm{M}-\mathrm{HCl}$.

DNA purification. The method used was a modification of the procedure described by Marmur (1961). Sodium dodecyl sulphate was added to the disrupted mycelial/arthrospore suspension to a final concentration of $1 \%(\mathrm{w} / \mathrm{v})$. This mixture was then agitated in a $500 \mathrm{ml}$ conical flask at constant speed with a magnetic stirrer for $1 \mathrm{~h}$ at room temperature. Sodium perchlorate was then added to a final concentration of $1 \mathrm{M}$ and the mixture was stirred for a further $1 \mathrm{~h}$ at room temperature. An equal volume of chloroform/isoamyl alcohol $/ 90 \%(\mathrm{v} / \mathrm{v})$ phenol $(24: 1: 25$, by vol.) was added and the resulting emulsion was stirred for $2 \mathrm{~h}$ (Butterworth, 1976). The emulsion was then centrifuged at $18000 \mathrm{~g}$ at $4{ }^{\circ} \mathrm{C}$ for $10 \mathrm{~min}$, and the upper, aqueous layer containing the DNA was removed. The impure DNA was precipitated overnight with $1 \cdot 3 \mathrm{vol}$. chilled ethanol. The flocculent precipitate was collected by centrifuging at $10000 \mathrm{~g}$ at $4{ }^{\circ} \mathrm{C}$ for $10 \mathrm{~min}$ and redissolved in approximately $10 \mathrm{ml}$ of $0 \cdot 1 \times \mathrm{SSC}$ buffer (SSC buffer is $0.15 \mathrm{M}-\mathrm{NaCl}$ and $0.015 \mathrm{M}$-trisodium citrate, $\mathrm{pH} 7 \cdot 0$ ). The buffer concentration was adjusted to that of SSC and bovine pancreatic ribonuclease was added (final concentration $20 \mu \mathrm{g} \mathrm{ml}^{-1}$ ) and incubated for $4 \mathrm{~h}$ at room temperature. Residual proteins were removed by treatment with chloroform/isoamyl alcohol $(24: 1, \mathrm{v} / \mathrm{v})$ and the upper aqueous layer was then separated by centrifuging at $18000 \mathrm{~g}$ for $10 \mathrm{~min}$ at $4{ }^{\circ} \mathrm{C}$. The DNA was selectively precipitated with chilled propan-2-ol in the presence of $0.3 \mathrm{M}$-sodium acetate and 0.001 M-EDTA. The DNA was redissolved in $0 \cdot 1 \times \mathrm{SSC}$ buffer and stored at $4{ }^{\circ} \mathrm{C}$ over a few drops of chloroform. If necessary the DNA was deproteinized again with chloroform/isoamyl alcohol $(24: 1, \mathrm{v} / \mathrm{v})$, and reprecipitated with $1 \cdot 3$ vol. chilled ethanol.

Estimation of base composition. Buoyant density of the DNA was determined by equilibrium centrifugation in a neutral $\mathrm{CsCl}$ density gradient (Meselson et al., 1957). The DNA of Micrococcus lysodeikticus (Sigma) was used as a density marker; its buoyant density was taken to be $1.731 \mathrm{~g} \mathrm{ml}^{-1}$ (Schildkraut et al., 1962). The mean DNA base composition ( $\mathrm{mol} \% \mathrm{G}+\mathrm{C}$ ) was then calculated from the buoyant density by the equation of Schildkraut et al. (1962): $\rho=0 \cdot 098(\mathrm{GC})+1 \cdot 660$, where GC is the mole fraction of G $+\mathrm{C}$, and $\rho$ is the buoyant density $\left(\mathrm{g} \mathrm{ml}^{-1}\right)$. The determination was repeated twice for each DNA sample and the mean value was used to calculate $\% \mathrm{G}+\mathrm{C}$. DNA extractions from some strains were repeated to check the reproducibility between different batches of the same culture and the reliability of the extraction procedures. The base compositions of some strains were also estimated from melting temperature $\left(T_{m}\right)$ measurements in $0 \cdot 1 \times \mathrm{SSC}$ buffer according to the method of Marmur \& Doty (1962) and calculated as described previously (Owen et al., 1978).

\section{RESULTS}

For the majority of dermatophyte cultures the DNA preparation procedure yielded sufficient amounts of fibrous DNA (about $1 \mathrm{mg}$ ) for repeated $\mathrm{G}+\mathrm{C}$ estimations. However, difficulties were sometimes experienced in that a flocculent DNA precipitate was obtained, which had to be collected by centrifugation. This was attributed to degradation of the DNA during trituration with liquid nitrogen.

The mean base compositions for the chromosomal DNA of strains are listed in Table 1. For all 55 strains, values were in the range $48 \cdot 7$ to $50 \cdot 3 \% \mathrm{G}+\mathrm{C}$. Good reproducibility $( \pm 0.4 \% \mathrm{G}+\mathrm{C})$ was found on repeated estimates for each strain; variations between different preparations were insignificant. Most of the strains tested had satellite DNA peaks 
with lower $\mathrm{G}+\mathrm{C}$ values, ranging from $14 \cdot 7$ to $30 \cdot 8 \% \mathrm{G}+\mathrm{C}$ (Table 2 ). The satellite DNA normally represented around $10 \%$ of the total DNA extracted. However, the $\mathrm{G}+\mathrm{C}$ content of the satellite DNAs from some strains varied on repeated DNA extractions and in repeated determinations on DNA from the same extraction. The commonest satellite peak was assumed to be mitochondrial in origin, whereas other peaks, when present, were possibly nuclear DNA or DNA contaminated with polysaccharide (Storck \& Alexopoulos, 1970). The two clinically common species Trichophyton mentagrophytes and T. rubrum had almost identical mean $\mathrm{G}+\mathrm{C}$ contents of $49 \cdot 7 \pm 1 \cdot 0 \%$ (8 strains) and $49 \cdot 6 \pm 0.5 \%$ (8 strains), respectively. The other 14 species of Trichophyton had $\mathrm{G}+\mathrm{C}$ values that differed by no more than $1 \%$ from those of $T$. mentagrophytes or T. rubrum. Close similarities in $\mathrm{G}+\mathrm{C}$ content were likewise found for the species of Microsporum (16 species had a mean $\mathrm{G}+\mathrm{C}$ of $49.9 \%$ ).

Estimations of $\mathrm{G}+\mathrm{C}$ contents from the melting temperature showed close agreement with those from the buoyant density technique and indicate that the chromosomal DNA probably did not have any unusual molecular features such as atypical bases or covalent modifications.

\section{DISCUSSION}

The dermatophytes examined in this study constituted a remarkably homogeneous group of micro-organisms with respect to their mean chromosomal $\mathrm{G}+\mathrm{C}$ contents when compared with other fungi, in particular those of medical importance. Some genera, for example Candida, contain species with widely differing $\mathrm{G}+\mathrm{C}$ contents (Storck \& Alexopoulos, 1970): this variation is direct evidence of the confused taxonomic state of the genus.

The dermatophyte genera and species are defined and identified in the routine laboratory by traditional mycological criteria based on morphological characteristics and on a rather limited range of biochemical tests. In some cases, the differences used for classification purposes are rather trivial; for example, some species of Trichophyton are differentiated by minor variations in the structure of their microconidia. Other more recent approaches in which differences have been observed are based on nutritional requirements, mating compatibility with tester strains of sexually reproductive species and comparative analysis of antigens (Philpot, 1978). It must be assumed that such differences reflect only a small part of the information content of the genome because they do not appear to correlate with any obvious difference in the overall base compositions of the chromosomal DNA. Furthermore, although dermatophytes have become adapted to a wide range of environments, and have developed varying degrees of preference for human, animal and soil substrates, this has not been accompanied by any divergence in their $\mathrm{G}+\mathrm{C}$ contents.

The principal objective of this study was to determine if differences between representative species of dermatophytes classified by orthodox mycological criteria were also manifested by differences in their DNA base composition. Our results showed that $G+C$ contents of chromosomal and satellite DNA of the various dermatophyte species were essentially similar and therefore of no practical value in genus or species differentiation. The fact that the strains had almost identical chromosomal $\mathrm{G}+\mathrm{C}$ contents indicated the likelihood of a high level of taxonomic similarity between the various genera and species. The $\mathrm{G}+\mathrm{C}$ contents of the satellite DNAs varied between strains and consistent differences between species were not apparent so they had no application in classification. Studies with bacteria (Jones \& Sneath, 1970), showed that the DNAs of organisms belonging to the same species should differ by no more than 3 to $4 \% \mathrm{G}+\mathrm{C}$, and those of organisms belonging to the same genus should differ by no more than $10 \% \mathrm{G}+\mathrm{C}$. Base compositions may therefore be used to exclude an organism from a taxon, but not as the sole criterion to include one. On this basis, our results for the dermatophytes do not contradict the present taxonomic arrangement, neither do they exclude any alternative arrangement in which dermatophytes could constitute a single genus of several species, or even a single species with several subspecies. We suggest, in view of the high overall degree of phenetic and genomic similarity exhibited 
Table 1. Dermatophyte species examined and mean DNA base composition

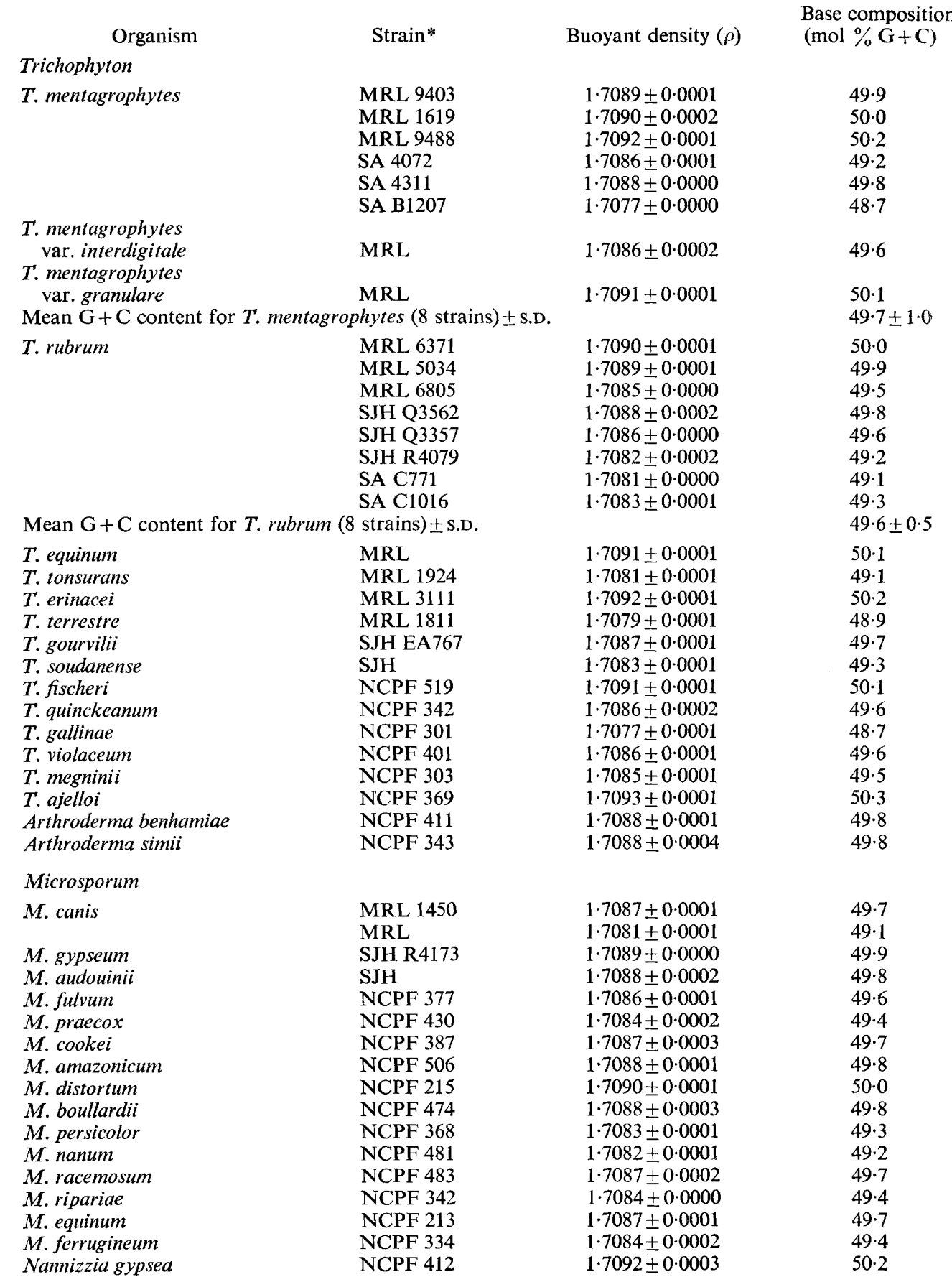


Table 1. (Continued)

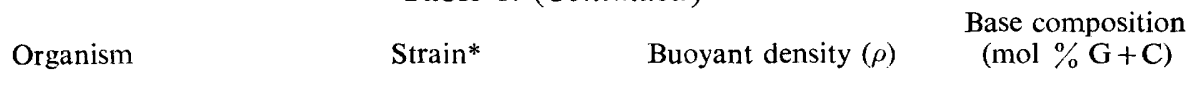

Epidermophyton

E. floccosum

MRL
MRL 2011
MRL 2108
MRL 1613
SJH R1947
SJH ER6375
SJH ER6513

$49 \cdot 8$

$1 \cdot 7090 \pm 0 \cdot 0001$

$1.7089 \pm 0.0000 \quad 49.9$

$1 \cdot 7085 \pm 0.0001 \quad 49 \cdot 5$

$1 \cdot 7092 \pm 0.0002 \quad 50 \cdot 2$

$1 \cdot 7087 \pm 0 \cdot 0002 \quad 49 \cdot 2$

$1 \cdot 7092 \pm 0 \cdot 0002 \quad 50 \cdot 2$

$49 \cdot 8 \pm 0 \cdot 4$

Mean $\mathrm{G}+\mathrm{C}$ content for $E$. floccosum ( 7 strains) \pm s.D.

$1 \cdot 7083 \pm 0 \cdot 0003 \quad 49 \cdot 3$

E. stockdaleae

NCPF 472

$1 \cdot 7147 \pm 0.0001$

$55 \cdot 8$

(fast-growing strain)

Hendersonula toruloidea

(slow-growing strain)

SJH

$1 \cdot 7147 \pm 0 \cdot 0001$

$55 \cdot 9$

$\mathrm{SJH}$

$1 \cdot 7148 \pm 0 \cdot 0001$

$56 \cdot 2$

Scytalidium hyalinum

SJH

$1 \cdot 7151 \pm 0 \cdot 0002$

$56 \cdot 2$

* MRL, clinical isolate from the Mycological Reference Laboratory, London School of Hygiene and Tropical Medicine, London; SJH, clinical isolate from the Mycology Department, St John's Hospital for Diseases of the Skin, London; NCPF, stock strain from the National Collection of Pathogenic Fungi at the Mycological Reference Laboratory, London School of Hygiene and Tropical Medicine, London; SA, provided by Dr C. Young, Institute of Medical Research, University of Witwatersrand, Johannesburg, South Africa.

Table 2. Summary of the base compositions of chromosomal and satellite DNAs of dermatophyte genera

Base composition $(\mathrm{mol} \% \mathrm{G}+\mathrm{C})$

\begin{abstract}
Genus
Trichophyton

Microsporum

Microsporum 17 (16 species)
Epidermophyton 8 (2 species)

No. of strains

30 (16 species)
\end{abstract}

\begin{tabular}{cr} 
Chromosomal DNA \\
\hline Range & Mean \pm S.D. \\
$48 \cdot 7-50 \cdot 3$ & $49 \cdot 6 \pm 0 \cdot 44$ \\
$49 \cdot 1-50 \cdot 2$ & $49 \cdot 6 \pm 0 \cdot 41$ \\
$49 \cdot 2-50 \cdot 2$ & $49 \cdot 8 \pm 0 \cdot 32$
\end{tabular}

$\begin{array}{cc}\text { Satellite DNA } \\ \text { Range } & \text { Mean } \pm \text { S.D. } \\ 21 \cdot 4-30 \cdot 1 & 24 \cdot 6 \pm 1 \cdot 5 \\ 14 \cdot 7-30 \cdot 8 & 25 \cdot 5 \pm 5 \cdot 6 \\ 16 \cdot 0-28 \cdot 8 & 28 \cdot 0 \pm 4 \cdot 7\end{array}$

by the dermatophytes, that the distinctions made on existing mycological characteristics may not be fully justified. For a more precise understanding of the taxonomic relationships amongst the dermatophytes, the use of DNA base pairing procedures may be helpful in establishing the validity of the species as currently defined.

We are grateful to Dr M. S. Pereira, Virus Reference Laboratory, Central Public Health Laboratory, for the use of ultracentrifuge facilities. This work was supported by a Wellcome Trust grant.

\section{REFERENCES}

Butterworth, P. H. W. (1976). In Subnuclear Components: Preparation and Fractionation, pp. 295-322. Edited by G. D. Birnie. London: Butterworth.

Campbell, C. K. \& Mulder, J. L. (1977). Skin and nail infection by Scytalidium hyalinum sp. nov. Sabouraudia 15, 161-166.

Gentles, J. C. \& Evans, E. G. V. (1970). Infection of the feet and nails with Hendersonula toruloidea. Sabouraudic 8, 72-75.

Jones, D. \& SN EATH, P.H. A. (1970). Genetic transfer and bacterial taxonomy. Bacteriological Reviews 24, 40-81.

MARMUR, J. (1961). A procedure for the isolation of DNA from microorganisms. Journal of Molecular Biology 3, 208-218.

Marmur, J. \& Doty, P. (1962). Determination of the base composition of deoxyribonucleic acid from its thermal denaturation temperature. Journal of Molecular Biology 5, 109-118.

Mendonça-Hagler, L. D., Travassos, L. R., Lloyd, K. O. \& Phaff, H. J. (1974). DNA base composition and hybridisation studies on the human pathogen Sporothrix schenckii and Ceratocystis species. Infection and Immunity $\mathbf{9}$, 934-938. 
Meselson, M., Stahl, F. W. \& Vinograd, J. (1957). Equilibrium sedimentation of macromolecules in density gradients. Proceedings of the National Academy of Sciences of the United States of America 43, 581-588.

Normore, W. M. (1973). Guanine plus cytosine (GC) composition of the DNA of bacteria, fungi, algae and protozoa. In CRC Handbook of Microbiology, vol. 11, Microbial Composition, pp. 585740. Edited by A. I. Laskin \& H. A. Lechevalier. Cleveland: CRC Press.

Owen, R. J., Legros, R. M. \& Lapage, S. P. (1978). Base composition, size and sequence similarities of genome deoxyribonucleic acids from clinical isolates of Pseudomonas putrefaciens. Journal of General Microbiology 104, 127-138.

Philpot, C. M. (1978). Serological differences among the dermatophytes. Sabouraudia 16, 247256.

Rebell, G. \& TAPlin, D. (1978). Dermatophytes: Their Recognition and Identification, revised edn. Coral Gables: University of Miami Press.

Schildkraut, C. L., Marmur, J. \& Doty, P. (1962). Determination of the base composition of DNA from its buoyant density in $\mathrm{CsCl}$. Journal of Molecular Biology 4, 430-443.

Storck, R. \& Alexopoulos, C. J. (1970). DNA of fungi. Bacteriological Reviews 34, 126-154. 